\title{
The Influence of Consumer Ethnocentrism on Buying Behavior - The Case of Azerbaijan
}

\author{
Shahin Akbarov, Asya Cafarova \\ Azerbaijan State University of Economics / UNEC, Azerbaijan.
}

\begin{abstract}
The purpose of this research is to reveal the ethnocentrism level of Azerbaijani consumers and to determine the effect of ethnocentric tendencies of consumers on purchases. 317 questionnaire was collected through a convenience sample. Data were analyzed with SPSS. Mean analysis was conducted to determine the ethnocentric level of consumers. T-test was performed to determine the differences between demographic groups in terms of ethnocentric tendencies. Regression analysis was performed to determine the effect of ethnocentric tendency on purchases. The results show that the consumer ethnocentrism level of Azerbaijani consumers is low, and the higher the consumer ethnocentrism level the higher the likelihood of purchasing domestic products.
\end{abstract}

Keywords: Consumer ethnocentrism, CETSCALE, Azerbaijan

\section{INTRODUCTION}

Consumer ethnocentrism always is an actual issue. Much research has been done about the consumer ethnocentrism level of consumers and its impact on purchasing behavior (Florian and Blut, 2008; Adnan and Khan, 2017; Chowdhury, 2013; Bandara ve Miloslava, 2012; Jiménez et al., 2014). Studies show that people with high levels of consumer ethnocentrism will prefer to buy domestic products (Prince et al., 2019; Pentz et al., 2017). However the impact of consumer ethnocentrism on purchasing domestic goods may vary depending on some factors, namely, the development level of the country, the quality and availability of domestic goods, and so on (Akbarov, 2021).

There are few studies on this subject in Azerbaijan. This study aims to answer the following question:

1. What is the consumer ethnocentrism level of Azerbaijani consumers?

2. Are there differences between demographic groups regarding consumer ethnocentrism level?

3. Is there a significant effect of consumer ethnocentrism on purchasing behavior?

We first reviewed literature in the related field. After then the results of the empirical study are presented. The paper concludes with a discussion section.

\section{LITERATURE REVIEW}

\subsection{Ethnocentrism}

The term ethnocentrism was introduced to the social science literature in 1906 by Sumner (Neuliep et al., 2005). He defined ethnocentrism as "a view in which one's own group is the center of everything, and all others are scaled and rated in reference to it" (Altintaş and Tokol, 2007). The original term, ethnocentrism, referred to a situation where individuals would associate themselves with and prefer their own group (in-group) while distancing themselves from and rejecting other groups (out-groups) (Pentz et al., 2017). Ethnocentrism often serves the socially useful function of encouraging cohesion and solidarity among 
group members, however, it can also cause such attitudes as superiority, intolerance, and look down on those with different customs and lifestyles (Caruana, 1996). Luque-Martinez et al. (2000) state that ethnocentrism represents universal tendency to see an individual's own group as the center of the universe, thus rejecting those individuals who are culturally different and blindly accepting those who are culturally similar (Jiménez-Guerrero et al., 2014).

\subsection{Consumer Ethnocentrism}

"Consumer ethnocentrism" was construed by Shimp and Sharma (1987) as a sub-set of ethnocentrism (Shankarmahesh, 2006). In 1987, the concept of "consumer ethnocentrism", which is the consumer dimension of "ethnocentrism", was introduced for the first time in the study conducted by Sharma and Shimp in order to measure the attitudes and behaviors of American consumers towards using foreign products (Ar1 \& Mardan, 2011). Consumer ethnocentrism gives a person identity in a functional sense, creates a sense of belonging, and determines which purchasing behaviors they accept and which purchasing behaviors they cannot accept in their social group (Yener, 2014). Consumer ethnocentrism is the nationalism in the economic sphere, which bears the basic characteristics of nationalism, and its tendencies in the form of non-purchasing or boycott based on moral and social grounds for fear that foreign products will harm individuals and the country's economy (Uyar and Dursun, 2015). Consumers who have an ethnocentric tendency will buy domestic products even if the domestic product is lower than the imported product in terms of price/quality performance, and the domestic product always comes first for them. Therefore, consumers with an ethnocentric tendency support the purchase of domestic products and accept that it is not right to purchase foreign products. From an economic point of view, ethnocentric-oriented consumers think that imported products will harm the domestic economy and labor force and cause job loss, that is, unemployment. From a moral aspect they think, people who love their country and nation should buy domestic products, and that buying foreign products is not right, and contradicts nationalism (Bawa, 2004; Teo et al., 2011).

\subsection{CETSCALE}

The "Consumer Ethnocentric Tendency Scale" (CETSCALE) was developed by Shimp and Sharma. The CETSCALE scale helps to determine the consumer tendencies to consume domestic and imported products (Toksar1 and Senir, 2015; Çilingir, 2014). The CETSCALE scale consists of 17 items gathered under one dimension. It is presented as a Likert scale in applications. However, various authors also used short forms (10-statement, 6-statement, 5 -statement, and 4-statement forms) in which the scale was reliable and valid (Türkmen and Köroğlu, 2017).

\section{METHODOLOGY}

The purpose of this research is to reveal the ethnocentrism level of Azerbaijani consumers and to determine the effect of ethnocentric tendencies of consumers on purchases. The differences between demographic groups were also investigated. 317 questionnaire was collected through a convenience sample.

CETCALE (17 items) was used to measuring the level of consumer ethnocentrism. A 5-point Likert-type scale (1- strongly disagree and 5-strongly agree) was used.

Consumers were also asked to indicate whether they preferred domestic or foreign products when purchasing products. The related categories are presented as such: "1 - only foreign, 2 - mostly foreign, 3 - it does not matter/both, 4 - mostly domestic, 5- only domestic".

Data were analyzed with SPSS. Mean analysis was conducted to determine the ethnocentric level of consumers. T-test was performed to determine the differences between demographic groups in terms of ethnocentric tendencies. Regression analysis was performed to determine the effect of ethnocentric tendency on purchases. 


\section{ANALYSES}

\subsection{Demographic characteristics of the sample}

The sample consists of $73.5 \%$ younger people, $58.6 \%$ women, $74.5 \%$ single people, and $55.2 \%$ low-income people (Table 1).

Table 1. Demographic characteristics of the sample

\begin{tabular}{llcl}
\hline \multirow{2}{*}{ Age } & Younger & 233 & 73,5 \\
& Older & 84 & 26,5 \\
\hline \multirow{2}{*}{ Gender } & Men & 132 & 41,6 \\
& Women & 185 & 58,4 \\
\hline \multirow{2}{*}{ Marital status } & Married & 80 & 25,2 \\
& Single & 237 & 74,8 \\
\hline \multirow{2}{*}{$\begin{array}{l}\text { Monthly } \\
\text { income }\end{array}$} & Lower & 175 & 55,2 \\
& income & & \\
& Higher & 142 & 44,8 \\
\hline
\end{tabular}

\subsection{Mean Value for CETSCALE Items}

Table 2 demonstrates the ethnocentric level of consumers. According to the results of the mean analysis, the value of 6 items range from 3,01 to 3,52; the value of 3 items range from 2,51 to 3,00; the value of 7 items range from 2,01 to 2,50; the value of 1 item is under 2,00. The mean score for CETSCALE is 2,67.

Table 2. Mean Value for CETSCALE Items

- Buy Azerbaijan-made products, keep Azerbaijani working

- Azerbaijani products, first, last, and foremost.

- We should buy from foreign countries only those products that we cannot obtain within our own country.

- There should be very little trading or purchasing of goods from other countries unless out of necessity.

- Azerbaijan people should always buy Azerbaijan-made products instead of imports

- Only those products that are unavailable in Azerbaijan should be imported

- We should purchase products manufactured in Azerbaijan instead of letting other countries get rich off us.

- Azerbaijanis should not buy foreign products because this hurts Azerbaijani business and causes unemployment.

- It is always best to purchase Azerbaijani products.

- Foreign products should be taxed heavily to reduce their entry into the Azerbaijani.

- It may cost me in the long-run but I prefer to support Azerbaijani products.

- Foreigners should not be allowed to put their products on our markets.

- Azerbaijani consumers who purchase products made in other countries are responsible for putting their fellow Azerbaijanis out of work.

- A real Azerbaijani should buy Azerbaijan-made products

- It is not right to purchase foreign products.

- Purchasing foreign-made products is un-Azerbaijani

- Curbs should be put on all imports. 


\subsection{Analysis of Differences}

The results of the T-tests regarding the differences between demographic groups are presented in Table 4. According to the results, the level of consumer ethnocentrism differs between men $(2,533)$ and women $(2,774)$, married $(2,858)$ and singles $(2,611)(\mathrm{p}<0.05)$. Women are more ethnocentric than men; married are more ethnocentric than singles. There are no differences regarding age and income groups $(p>0.05)$.

Table 4. The Results of the T-tests

\begin{tabular}{|c|c|c|c|c|c|c|}
\hline Test Variables & $\begin{array}{l}\text { Grouping } \\
\text { Variables }\end{array}$ & Groups & Mean & $\begin{array}{c}\text { Std. } \\
\text { Deviation }\end{array}$ & $\mathbf{t}$ & $\mathbf{p}$ \\
\hline \multirow{4}{*}{$\begin{array}{l}\text { Consumer } \\
\text { ethnocentrism }\end{array}$} & Gender & $\begin{array}{l}\text { Men } \\
\text { Women }\end{array}$ & $\begin{array}{l}2,533 \\
2,774\end{array}$ & $\begin{array}{l}0,924 \\
0,972\end{array}$ & $\begin{array}{c}- \\
2,221\end{array}$ & 0,027 \\
\hline & $\begin{array}{l}\text { Marital } \\
\text { status }\end{array}$ & $\begin{array}{l}\text { Married } \\
\text { Single }\end{array}$ & $\begin{array}{l}2,858 \\
2,611\end{array}$ & $\begin{array}{l}1,040 \\
0,925\end{array}$ & 2,001 & 0,046 \\
\hline & Age & $\begin{array}{l}\text { Younger } \\
\text { Older }\end{array}$ & $\begin{array}{l}2,623 \\
2,814\end{array}$ & $\begin{array}{l}0,928 \\
1,030\end{array}$ & $\begin{array}{c}- \\
1,567\end{array}$ & 0,118 \\
\hline & $\begin{array}{l}\text { Monthly } \\
\text { income }\end{array}$ & $\begin{array}{l}\text { Lower } \\
\text { income } \\
\text { Higher } \\
\text { income }\end{array}$ & $\begin{array}{r}2,740 \\
2,592\end{array}$ & $\begin{array}{l}0,951 \\
0,964\end{array}$ & 1,375 & 0,170 \\
\hline
\end{tabular}

\subsection{The Effect of Consumer Ethnocentrism on Purchasing Behavior}

For regression analysis, 17 items of CETSCALE were computed as one variable (independent variable). Consumer ethnocentrism explains $34,4 \%$ of the variance of purchasing behavior. When consumer ethnocentrism goes up by 1 , the tendency to purchase domestic products goes up by $0.362(\mathrm{p}<0,000)$.

Table 5. The Result of the Regression Analysis

\begin{tabular}{lllllll}
\hline $\begin{array}{l}\text { Independent } \\
\text { variable }\end{array}$ & $\begin{array}{l}\text { Dependent } \\
\text { variable }\end{array}$ & B & Beta & $\mathbf{R}^{\mathbf{2}}$ & F & Sig. \\
\hline $\begin{array}{l}\text { Consumer } \\
\text { ethnocentrism }\end{array}$ & $\begin{array}{l}\text { Purchasing } \\
\text { behavior }\end{array}$ &, 362 &, 586 &, 344 & 164,990 &, 000 \\
\hline
\end{tabular}

\section{DISCUSSION}

In this study the consumer ethnocentrism level of people, the differences between demographic groups regarding consumer ethnocentrism, and the effect of consumer ethnocentrism on purchasing behavior were examined.

The results of this study indicate that the consumer ethnocentrism level of Azerbaijani consumers is low $(2,67$ out of 5,00$)$ (This result is consistent with Rojas-Méndez and Chapa (2019).). It is good news for foreign companies, but not good for domestic companies. Because results also show that the higher the consumer ethnocentrism level, the higher the consumption of domestic products (This result is consistent with Xin and Seo (2019), and Thomas et al. (2019).). Domestic firms and government can promote consumer ethnocentrism. Campaigns regarding this promotion will raise the consumer ethnocentrism level of individuals. It is important for both government and domestic firms. The government wants to reduce imports and support domestic firms. Domestic firms want to compete against multinational brands. Raising the consumer ethnocentrism level of consumers will result in buying domestic products.

Women are more ethnocentric than men, and married individuals are more ethnocentric than singles. According to these results, one can assume that married individuals and women may be a target of domestic companies than men and singles. However, it is not clear to what degree is the consumer ethnocentrism level of these groups will result in buying domestic products. Therefore, it can be concluded that if other factors are equal, 
women will buy more domestic products than men, and married individuals will buy more domestic products than singles.

The results of this study reveal that age and income groups show the same level of consumer ethnocentrism.

One of the main shortcomings of this study is the sampling method. Thus convenience sampling is a problematic method for the generalization of the results. Second, some other variables, for example, country of origin, quality, and so on, might be included in the model. Third, some moderation variables might provide comprehensive and valuable findings.

\section{REFERENCES}

[1]. Adnan, A., Khan, M. N. (2017), "Implications of Ethnocentric Tendencies among Indian Car Buyers: Scale Refinement and Analysis of Dimensionality", Pacific Business Review International Volume Vol. 10 No. 3, pp. 57-68.

[2]. Akbarov, S. (2021), "Consumer ethnocentrism and purchasing behavior: moderating effect of demographics", Journal of Islamic Marketing, Vol. ahead-of-print No. ahead-of-print. https://doi.org/10.1108/JIMA-02-2020-0047.

[3]. Altintass M. H. and Tokol T. (2007), "Cultural openness and consumer ethnocentrism: an empirical analysis of Turkish consumers", Marketing Intelligence \& Planning, Vol. 25 No. 4, pp.308-325, https://doi.org/10.1108/02634500710754565

[4]. Ari, E. S., Madran, C. (2011), "The Role of Consumer Ethnocentrism and Country of Origin Effect on Purchase Decision", Öneri Dergisi, Vol. 9 No. 35, pp. 15-33, doi:10.14783/od.v9i35.1012000248.

[5]. Bandara, W. W. M. C., Miloslava, C. (2012), "Consumer Ethnocentrism and Attitudes Towards Foreign Beer Brands: With Evidence from Zlin Region in the Czech Republic", Journal of Competitiveness, Vol. 4 No 2, pp. 3-19, 10.7441/joc.2012.02.01.

[6]. Bawa, A. (2004), "Consumer Ethnocentrism: CETSCALE Validation and Measurement of Extent", Vikalpa: The Journal for Decision Makers, Vol. 29 No. 3, pp. 43-57, https://doi.org/10.1177/0256090920040304.

[7]. Caruana A. (1996), "The effects of dogmatism and social class variables on consumer ethnocentrism in Malta", Marketing Intelligence \& Planning, Vol. 14 No. 4, pp.39-44, https://doi.org/10.1108/02634509610121569

[8]. Chowdhury, T. A. (2013), "Understanding Consumer Ethnocentrism in Developing Countries: Case Bangladesh", Journal of Global Marketing, Vol. 26 No. 4, pp. 224-236, https://doi.org/10.1080/08911762.2013.814821.

[9]. Çilingir, Z. (2014), "Consumer Ethnocentrism Tendencies Scale (Cetscale): A Pilot Study For Consumers in Istanbul", International Journal of Economic and Administrative Studies, Vol. 13, pp. 209-232.

[10]. Florian, H. E., Blut, W. D. W. M. (2008), "Consumer ethnocentrism in the German market", International Marketing Review, Vol. $25 \quad$ No. $1, \quad$ pp. $\quad$ 7-32, http://dx.doi.org/10.1108/07363760410558663.

[11]. Jiménez-Guerrero J.F., Gázquez-Abad J.C. and Linares-Agüera E.C. (2014), "Using standard CETSCALE and other adapted versions of the scale for measuring consumers' ethnocentric tendencies: An analysis of dimensionality", BRQ Business Research Quarterly, Vol. 17, pp. 174-190

[12]. Jiménez-Guerrero, J. P., Gázquez-Abad, J. C., Linares-Agüera, E.C. (2014), "Using standard CETSCALE and other adapted versions of the scale for measuring consumers' ethnocentric tendencies: An analysis of dimensionality”, BRQ Business Research Quarterly, Vol. 17, No. 3, pp: 174-190. https://doi.org/10.1016/j.cede.2013.06.003.

[13]. Luque-Martinez, T., Ibanez-Zapata, J. -A., Barrio-Garcia, S. (2000), "Consumer ethnocentrism measurement An assessment of the reliability and validity of the CETSCALE in Spain", European Journal of Marketing, Vol. 34 No. 11/12, pp. 1353-1374, https://doi.org/10.1108/03090560010348498.

[14]. Neuliep J.W., Hintz S.M. and McCroskey J.C. (2005), "The influence of ethnocentrism in organizational contexts: perceptions of interviewee and managerial attractiveness, credibility, and effectiveness", Communication Quarterly, Vol. 53 No. 1, pp. 41-56, DOI: $10.1080 / 01463370500055954$

[15]. Pentz C., Terblanche N. and Boshoff C. (2017), "Antecedents and consequences of consumer ethnocentrism: evidence from South Africa", International Journal of Emerging Markets, Vol. 12 No. 2, pp.199-218, https://doi.org/10.1108/IJoEM-09-2015-0189 
[16]. Pentz, C., Terblanche, N. and Boshoff, C. (2017), "Antecedents and consequences of consumer ethnocentrism: evidence from South Africa", International Journal of Emerging Markets, Vol. 12 No. 2, pp. 199-218, doi: 10.1108/IJoEM-09-2015-0189.

[17]. Prince, M., Yaprak, A. and Palihawadana, D. (2019), "The moral bases of consumer ethnocentrism and consumer cosmopolitanism as purchase dispositions", Journal of Consumer Marketing, Vol. 36 No. 3, pp. 429-438, doi: 10.1108/JCM-11-2017-2432.

[18]. Rojas-Méndez, J. and Chapa, S. (2019), "X-Scale: a new scale to measure consumer xenocentrism", Marketing Intelligence and Planning, Vol. 38 No. 3, pp. 354-368. doi: 10.1108/MIP-01-2019-0062.

[19]. Shankarmahesh M.N. (2006), "Consumer ethnocentrism: an integrative review of its antecedents and consequences", International Marketing Review, Vol. 23 No. 2, pp. 146-172, https://doi.org/ 10.1108/02651330610660065

[20]. Shimp T.A. and Sharma S. (1987), "Consumer Ethnocentrism: Construction and Validation of the CETSCALE", Journal of Marketing Research, Vol. 24, No. 3, pp. 280-289.

[21]. Teo, P. -C., Mohamad, O., Ramayah, T. (2011), "Testing the dimensionality of Consumer Ethnocentrism Scale (CETSCALE) among a young Malaysian consumer market segment," African Journal of Business Management. Vol.5 No. 7, pp. 2805-2816.

[22]. Thomas, T., Singh, N. and Ambady, K.G. (2019), "Effect of ethnocentrism and attitude towards foreign brands in purchase decision", Vision: The Journal of Business Perspective, Vol. 24 No. 3, pp. 1-10, doi: 10.1177/0972262919867509.

[23]. Toksari, M., Senir, G. (2015), "The Effect of Consumer Ethnocentrism on Purchasing Decision", The Sakarya Journal of Economics, Vol. 4 No. 3, pp. 19-28.

[24]. Türkmen, S., Köroğlu, A. (2017), "Consumer Ethnocentrism Scale: A Study of Reliability and Validity", Gastroia: Journal Of Gastronomy And Travel Research, Vol. 1 No. 1, pp. 36-46.

[25]. Uyar, K., Dursun, Y. (2015), "Foreign Branding in Different Product Category and Consumer Ethnocentrism", Journal of Social Sciences Institute, Vol. 19 No. 2, pp. 363-382.

[26]. Xin, L. and Seo, S. (2019), "The role of consumer ethnocentrism, country image, and subjective knowledge in predicting intention to purchase imported functional foods", British Food Journal, Vol. 122 No. 2, pp. 448-464, https://doi.org/10.1108/BFJ-05-2019-0326.

[27]. Yener, D. (2014), " Religiosity as a Factor That Affects Consumer Ethnocentrism", International Journal of Economic and Administrative Studies, Vol. 6 No. 12, pp.65-84. 